\title{
An Unsystematic Approach to Der Butt .
}

\section{LEONARD FORSTER}

Der Butt 1 is about the status of women in society, measured by two sets of co-ordinates, both of basic importance: sex and cookery. Each of these can be a power-factor in situations in which the relation between men and women is a hostile one; each can also be used, for this very reason, by ideologues for their own purposes. Grass, we know from his previous books, is suspicious of ideologues; here it is plain that he believes in the equality of the sexes, ${ }^{2}$ but that he also believes that certain roles are more suitable for one sex than for the other. No good comes if men try to play women's roles (though this is never explicitly shown); no good at all comes of it when women play men's roles. This is exemplified through the ages by a series of historical genre pictures.

The importance of myth and folk-tale in Grass's work has been generally recognised. In his earlier books it was implicit and often concealed; here it comes out into the open and Grass takes a well-known folk-tale as the peg on which to hang the action of his book. It is the tale collected by the artist Philipp Otto Runge on the island of Rügen and taken down in Low German from the lips of an old woman. The version we have, which he communicated to the Brothers Grimm and which they printed, ${ }^{3}$ relates how a fisherman catches a magic fish which has supernatural powers which can make wishes come true; how his wife Ilsebill keeps making him ask the fish for more and more material improvement and increased status for herself until having been made successively at the last emperor and pope she finally wants to be God Almighty, whereupon the fish loses patience and back fisherman and wife go to their original poverty. The tale can be interpreted on a variety of different levels: lamenting the vanity of human wishes; enjoining a gospel of moderation; deploring the insatiable desires of women and the gullibility of men; exposing a naked drive to power or a myth of female dominance; and so on. It is localised on the Baltic coast, which enables Grass to situate the action of his book on his favourite territory, the city of Danzig and the surrounding countryside.

$\mathrm{He}$ starts us with the dawn of prehistory on the Baltic, where there lives a tribe of three-breasted women who dispense milk and sex to their menfolk and by their control of these basic means of production keep them in subjection. The three-breasted woman is not unknown in folklore, ${ }^{4}$ though rare in normal 
life (three-testicled men are, it seems, more common than one would suppose, but Grass is not here concerned with them; in a further book, perhaps?). Grass's use of this figure is ingenious and original; the trimammary tribal mother Aua is the first of the gallery of female figures Grass displays before us (she, like Anna Blume, is 'so von vorne wie von hinten'). Each of them has a corresponding male protagonist, who is identified with the first-person narrator of the story and thus ultimately with Grass himself. Though the women are all different the man is always ultimately the same. As in the folk-tale, the women have names, the man as often as not remains anonymous.

We start off historically with men in a state of cosy and virtually mindless subjection to women. This is a static situation; there is no impulse making for change and it has existed for countless ages. Change comes from outside, through the agency of the magic fish, who instructs the male protagonist how to achieve a measure of liberation through hunting and fishing as opposed to female agriculture and elk-herding. Grass's myth of the origin of fire is similar to those familiar in folklore dealing with the theft of fire from some supernatural animal, 5 but it seems to be substantially his own invention. Fire in these myths stands for culture and everything it brings; here the culture-heroine steals fire from a cosmic wolf and the culture-hero acquires culture from a cosmic fish. In the scenes which ensue we follow the man-woman relationship down the ages, dealing sometimes with historical figures to whom actions are attributed which they are not known to have performed but which square with what is known of what they did perform. It has always been clear that Grass is a 'poeta doctus'; his use of history in his previous works has always been extensive. By this means he contrives to relativise the contemporary events he narrates (for instance in Die Blechtrommel) and at the same time to suggest the importance of a historical continuum of which they - and we - form a part. In Der Butt this continuum becomes explicit, becomes indeed one of the themes of the book. 6 It is expressed in a series of scenes set in the past, based on considerable detailed research and informed by the poet's imagination and empathy. The myth dimension, obvious in the earlier chapters, in fact accompanies the whole action of the book, reinforced and reintroduced at every turn by the figure of the mythical fish. The reader needs to keep Stith Thompson's Motif-Index of Folk-Literature, Frazer's Golden Bough, Bachofen's Mutterrecht and the Handwörterbuch des deutschen Aberglaubens within easy reach. Grass neatly avoids the purely historical approach, which would have reduced his tale to a series of Bilder aus der deutschen Vergangenheit of a kind drearily familiar since Gustav Freytag, with its nationalist overtones. Grass seems to echo the irreverent (but accurate) lines of Tucholsky in Gruß nach vorn:

Wer waren unsre Ahnen?

Kaschubische Germanen. 


\section{Die zeugten zur Erfrischung \\ Uns Promenadenmischung.}

He causes the fish to be caught by a trio of holidaying lesbians in a small boat in the Lübecker Bucht; after many vicissitudes the fish is tried by a self-appointed feminist tribunal for having instigated and master-minded male supremacy since the dawn of recorded history. The historical vignettes are presented as flashbacks, speeches by the fish in his own defence, sometimes in direct speech, sometimes through the recollections of the male narrator, but always with the distance and the irony that this situation implies. Like Grass's other novels this one has many strands; the historical dimension is only one, and we saw that the mythical dimension was another. Yet another is the pregnancy of Ilsebill, which is initiated on the very first page in what must be the most startling opening sequence of any novel in German literature; the book is divided into nine sections corresponding to the months of her pregnancy, and finally she is delivered - inevitably - of a female child. Ilsebill is a person of today, very much involved with the narrator as a person of today, but like him she also partakes of the nature of the various other female figures. A further strand is the interweaving of the themes of sex and cookery, with which the BalticSlavonic sub-theme of mushroom-gathering and mushroom-eating is closely associated; the phallic fungi which have been haunting Grass's drawings for years here find their literary application. A further strand is represented by the poems scattered at intervals throughout the book. By their number alone they represent the most important body of new poetry Grass has published for more than ten years. There were a few scattered poems in the other books, but here they form part of the structure and have a definite function; they present reflexion on the events recounted, often from a different angle, symbolic evocations of human predicaments. It must be said that they are very unequal; some are barely more than prose set out in lines of uneven length, some boldly exploit. powerful imagery by concise formulation. And there are other strands too. But at almost every point these strands are simultaneously present or implied, so that the texture of the book is much more closely woven than appears at first sight. We gradually become aware that the principal figures are the narrator (whom we will call Günter for convenience, to distinguish him from the author Grass) and his Ilsebill; in them the past is subsumed and their relations form the latest stage of the age-old tension between the sexes, the sex-war. Grass is concerned not with male or female supremacy but with the equality of the sexes, both in love and not; Ilsebill however turns out not to share these sentiments at all. She is not the only present-day incarnation of the female figures of history and prehistory; each one is present in one or other member of the feminist tribunal which tries the fish. (There are ironical touches here: the president of the tribunal is a Frau Dr. Schönherr; is it a mere coincidence that counsel for the prosecution should be called Sieglinde, like the 
formidable character in Örtlich betäubt, like her the daughter of a career officer, and that her surname, Huntscha, echoes hunčr, a Slavonic nursery word for 'pig'?)

Men as exploiters, women as exploited; but also vice versa. This is a too simple formulation. Grass is not only concerned with the exploitation of one sex by another, he is also - and much more fundamentally - concerned with the roles each sex plays in a common social existence $;^{7}$ these roles are not constant, they change with circumstances (men can be cooks, for instance), but only within certain basic limits. For a time Grass's graphic work was haunted by stern authoritarian male cooks in tall white hats (in Gleisdreieck for instance). This is not the way the male cook appears here however; here he is a mere accessory to the gallery of female cooks, a sort of scullion, just as throughout the book men are merely foils to the female characters who dominate the story except for the male narrator who has the whole thing under control.

The roles played by the main female characters are uniform. They act instinctively, without ideology. The advent of ideology involves a sort of fall from grace. Ideology is for men, practical warm-hearted but often hard-headed action is for women; the contrast between male and female roles in the matter of ideology is brought out very clearly in the characters of Lena Stubbe and August Bebel (esp. p. $540 \mathrm{ff}$ ). Down the ages women exercise power through sex and cookery; attempts to use other means are negative. Negative sex is ideology, emancipated lesbianism, barren reversal of roles. The feminist tribunal, the 'Feminal', is inspired by ideology, and the clichés rattle merrily as its deliberations proceed. This ideology is shown to be hollow and brittle; despite all the brave talk about female self-sufficiency every member of the tribunal secretly goes to bed with Günter during the hearings, some of them more than once. Where it all leads - indeed has led - is alarmingly shown up in the chapter 'Vatertag', of which more below.

A woman who exercises power otherwise than through sex and cookery is the original Ilsebill of the folk-tale. She incorporates a naked monomaniacal power-drive without reference to food or sex, neither of which play any part in the story. The magical powers of the fish render them unnecessary; she has not even got an ideology. Her power-drive is instinctive; we all have it, but she has more than most.

How about the fish, the central character of the book which bears his name? He has supernatural powers and extensive (though not complete) knowledge of the past and the future. He is immortal; if he is killed and cut up, the pieces join together again (p. 172). His designation is a masculine noun, but he seems to be sexless and has no love-life (apart from the dubious episode with Dorothea von Montau). He is a kind of 'Weltgeist' (p. 515), as indefinable and mysterious today as he was for the fisherman and his wife, a force of nature that one accepts for what it is without further inquiry. He influences the course of history in favour of the underdog. In the late Neolithic it was men who were 
being exploited; he helped them to escape from this situation and now, four thousand years later, he is prepared to exercise his powers in the opposite direction - or would have been, had the 'Feminal' not taken up the rigid ideological line it did. He allowed himself to be caught by women in the desire to help them to improve their lot against men; after his trial, when he is finally set at liberty in the Baltic, he makes no observation, promises nothing. We only see him once more: the widowed Maria Kuczorra, whose husband Jan died the victim of ideology and who is now building her own life, calls up the fish out of the sea and talks to him and gets new strength for life from him: "Ich hörte sie sprechen. Beide hörte ich sprechen. . . Maria lachte. . . Die sonst nie lachte, lachte knietief in der See. . . Schön, daß sie wieder lachen konnte" (p. 693). And as she strides back to the shore Günter sees in her the women of the past; she walks past him, she no longer needs him, she has found herself. "Ich lief ihr nach". No ideology, just clear-headed self-realisation. This is what the fish can do for women now, as he did for men before. "Nicht mehr mein Butt, ihr Butt". We are left at the end with the figure of this brave, self-sufficient widow, whom the fish will help, walking back confidently into life in Poland, where life is not easy.

It is worth drawing the parallel with an earlier woman who walked into the sea at just this place and invoked the fish: Dorothea von Montau (p. $170 \mathrm{ff}$ ), the ascetic, who had, like her sisters in the feminine tribunal, escaped from life into ideology; she raised the fish, but it did her no good. She did it for power only, like the fisherman's wife in the tale; like Ilsebill and Sieglinde Huntscha, she had a 'Ziegengesicht', and resembled them in other ways too.

II.

The narration is, as we saw, closely textured; the different threads and themes are interwoven and continuously present, so that from any one paragraph there is a way which leads to all of them. Let us take the first pages of the book as an example.

The first page presents the basic themes of the whole book: food and cookery; sex and the sex-war; the continuity of history; and finally love; but at the bottom of them all is the theme of equality, the equality of the sexes on which love must be based. The first short sentence is concerned with food: "Ilsebill salzte nach". Three words only, but there is more to it. Ilsebill and salt; from the start she is shown as an astringent character; there is to be nothing sweetly sentimental about her, she is to be blunt, hard-nosed, standing no nonsense, as her first remark later indicates. Meanwhile: "Bevor gezeugt wurde gab es Hammelschulter zu Bohnen und Birnen, weil Anfang Oktober". First food, then sex. Shoulder of mutton is an unusual dish in the German cuisine, only well thought of in Schleswig-Holstein, where the sheep graze on the salty grass between the dykes, the true 'pré salé'. Is this where we are? We are presumably in Wevelsfleth on the Holstein side of the Elbe estuary at the 
mouth of the Stör as pictured for us in Mariazuehren, in fact 'eingedeichte Wilstermarsch' (p. 654); they eat mutton there, especially in early autumn. First food, spiced by Ilsebill, then sex. She can hardly wait for it: "Beim Essen noch, mit vollem Mund, sagte sie: 'Wolln wir nun gleich ins Bett oder willst du mir vorher erzählen, wie unsre Geschichte wann wo begann?'". There is of course only one answer - the call of bed ("hörte ich dennoch, daß das Bett zuerst recht haben sollte"), and probably just as well, for this is the first page of the book and 'unsre Geschichte' is long, running to 694 pages.

"Ich, das bin ich jederzeit". So far we have only heard about Ilsebill; now we have the narrator, identifiable or half-identifiable as we proceed: Grass's narrator-persona who resembles him like a brother, whom we have agreed to call Günter in order to tell them apart. 'Unsre Geschichte' is not just a passing 'affair', nor yet a mere 'story', but 'history', and the actors in it are to be always the same under varying names and circumstances: "Ich, das bin ich jederzeit. Und auch Ilsebill war von Anfang an da". A human pair like Adam and Eve, perhaps 'musterhaft in Freud und Qual'. 'Von Anfang an' - when did this begin, this involvement of the sexes with one another beyond the basic needs of procreation? "Gegen Ende der Jungsteinzeit erinnere ich mich an unseren ersten Streit: rund zweitausend Jahre vor der Fleischwerdung des Herrn, als das Rohe und Gekochte in Mythen geschieden wurde". The sentence is loaded with oblique reference: 'vor der Fleischwerdung des Herrn' is a formulation of 'B.C.' which stresses the myth therein embodied; then there follows a reference to the structural mythology of Claude Lévi-Strauss Le cru et le cuit (1964). 'Im Sumpfland der Weichselmündung' - we are away from the Elbe estuary now, back to Grass's familiar stamping-ground; we are to see it from the end of the neolithic period onwards down to the Polish reconstructed Danzig of today: 'unsre Geschichte' in the continuity of history, sex, cookery and equality, beginning with 'die neolithische Köchin'. But meanwhile there is the presentday cook - a man. As in so many of Grass's books the first sentence is misleading or cryptic: "Ilsebill salzte nach" leads one to think at first that she was doing the cooking (further on we learn that she did in fact make the soup); we now realise that it is Günter who is the cook. He gives a mouth-watering description: "Ich hatte die Hammelschulter mit halben Knoblauchzehen gespickt und die in Butter gedünsteten Birnen zwischen grüne gesottene Brechbohnen gebettet" - lovingly heightened by the alliteration of dentals, labials and gutturals, all evocative of eating. Looking back we see that this delicious dish is not good enough for Ilsebill; she adds her own salt. As the book proceeds this turns out to be a pointer: nothing is ever good enough for Ilsebill. But for her, as for Günter, food and sex are closely linked; her remark about sex is spoken 'mit noch vollem Mund'. She has apparently been on the pill so far but on medical advice she has thrown the pills away and is now therefore ready to conceive; "das könne prompt anschlagen oder klappen". What is being described is not an act of sex for fun but an act of intended procreation, as in 
fact was already stated in the first line, where the verb 'zeugen' occurs.

"Also legten wir uns". . . the act of procreation, the basic act involving cooperation between the sexes: "Mal ich, mal sie oben. Gleichberechtigt". Here already at this early stage and in this fundamental form the basic theme of the book, the equality of the sexes, is firmly stated ("auch wenn Ilsebill meint. . ."). As the book proceeds it becomes apparent that equality is not going to be enough for Ilsebill; the sex-war is already adumbrated here, but it is not yet acute. There is love, which can overcome it; because they 'in Liebe zeugten' they achieve an 'Ausgleich'. Is this a balance or a compromise? Or a blessed state in which all opposites are resolved? Whatever it is, it is not a matter of course; behind the word 'Ausgleich' the sex-war is again perceptible, but for the time being 'doppelt waren wir tuichtig'. There follows an oblique reference to another great rambling novel which begins with an act of procreation, Tristram Shandy (it is mentioned elsewhere in the book) - for though the couple's exaltation beyond time is natural enough, the reference to the clock 'außer der Zeit und ihrem Ticktack' - is clear ('Have you not forgotten to wind up the clock?'). This act of procreation is not interrupted by absent-mindedness or boredom with a routine performance as with Sterne (the modern equivalent would be: 'Sam, the ceiling needs painting'); both partners have their minds on the job: "es klappte, schlug an, aus Zufall, mit Absicht und ohne weitere Zutat. Kaum war ich - wie ausgestoßen - draußen, sagte Ilsebill ohne grundsätzlichen Zweifel: ' $\mathrm{Na}$, diesmal wird es ein Junge'."

'Wie ausgestoßen' - a warning signal, the sex-war is again felt faintly in the background: all is not as well as it might seem. And in the event, as we find out at the end of the book, the child thus engendered is not a boy but a girl.

Then the culinary motif again: "Das Bohnenkraut nicht vergessen. Mit Salzkartoffeln oder historisch mit Hirse". What follows, we know by now, is to be concerned with the history of cookery. Then for the first time the important fish-soup motif is sounded; later it will appear that the soup is made from fish-heads boiled until they fall apart (p. 17-18), and here already the eyes swim in the soup and mean good luck - or should it be happiness ('Glück', p. 667)? The fish-head motif, which often occurs elsewhere in the book, is prefigured in Mariazuehren and in many of Grass's drawings and etchings; the 'Butt' himself, who has not been mentioned so far, is the successor to a long line of different fish, some of them shown merely as fish-heads speared on sticks. Mutton with beans and pears formed the subject of one of Grass's early poems in Die Vorzüge der Windhühner (1956). ${ }^{8}$

"Nachdem es geklappt haben mochte", they each smoke; Günter already miles away down the backstairs of history ("Ich lief, die Zeit treppab, davon") is called back to the present by Ilsebill: "Ubrigens brauchen wir endlich eine Geschirrspülmaschine". This at first sight purely practical remark is the beginning of another cluster of motifs. Cooking involves washing-up, and in the course of Grass's historical survey we see washing-up down the ages; it is an 
important accessory to the cookery theme. Over and above this, however, the dishwasher comes to symbolise Ilsebill's unsatisfied power-drive; even at this early stage it is perilously close to the 'Sam, the ceiling needs painting' situation. Later it becomes the centre of a motif-cluster: it has to be a noiseless dishwasher and it is associated with a trip to the West Indies and a 'Zweitwohnung' and much more besides (p. $117 \mathrm{ff}$ ). Gradually it becomes apparent that these things are more important to Ilsebill than Günter, than love, than the child she is just conceiving and which is born at the end of the book. The words 'in Liebe zeugten', we realise as we proceed, arose out of a misapprehension: Ilsebill, to whom Günter is so pathetically devoted, to whom he makes propitiatory noises throughout the book, is not interested in 'Gleichberechtigung' at all, and perhaps not even in love.

The act of procreation has been performed; Ilsebill is pregnant. Günter too is pregnant in a different sense - with eleven cooks in him all struggling to get out, all of them personified history (p. 13), examples, every one of them, of the amazing creativity and fertility of the author Günter Grass. And so Ilsebill's would-be hard-boiled remark: "Ich möchte dich mal schwanger erleben!" falls flat, beside the point which she has not the wit to see. The book is divided into sections according to her pregnancy, one for each month. "Und nach der Hammelschulter zu Bohnen und Birnen" which he had cooked, "gab sie mir neun Monate Zeit, meine Köchinnen auszutragen. Gleichberechtigt sind uns Fristen gesetzt".

'Gleichberechtigt' - hope springs eternal, but the concept is already acquiring a different flavour. Ilsebill's nine months are a present from Nature; Günter's nine months are a present from Ilsebill: there is nothing in the nature of artistic creativity which restricts him to nine months (how long did Goethe take over Faust? ). She graciously concedes him this time, while she is anyhow otherwise occupied (after that he is doubtless expected to devote all his time to her - and how about the child?). And so, without an unkind word being spoken, Ilsebill in the first two pages is shown in her true colours, selfish and power-hungry, a mean bitch. It is not for nothing that she bears the same name as the fisherman's wife. Günter, whether he knows it or not, is afraid of her.

III.

The way the poems fit into the whole structure is important; here are two examples.

The fish has told men about metals and patriarchy and the necessity of freeing oneself from the dominance of women: "Weg von der Brust. Ihr müßt euch entwöhnen" (p. 44). A flash-forward, and Günter tells Ilsebill that the fish is about to meet women and their accusations. "Indem er die Grimmsche Verfälschung seiner Legende verdámmte, sagte er: 'Dieses Märchen muß endlich vom Tisch" "(p. 45). There were two versions of the folk-tale about the fisherman and his wife; in the one we know the power-hungry partner is the 
wife, in the other it is the husband; later on we hear how Philipp Otto Runge collected both versions but how the Brothers Grimm would print only one of them. Later still, in 'Vatertag', we hear a purely sex-oriented version invented for the occasion (p. $612 \mathrm{ff}$ ). Either way, the story is an element in the sex-war for power, and the fish is going to join in by supporting female bids for power. At this point we have the poem 'Arbeit geteilt' (p. 45), with its first line "Wir das sind Rollen". This is about division of labour, functional, not power-conditioned, not bedevilled by questions of prestige, but a viable way of life in which each has a part to play: one keeps the soup hot, the other keeps the wine cool. But this ideal is too simple; at an early stage ("lange vor Karl dem Großen" - as we know, a very long time indeed before) men begin to change; the fish's teaching takes effect. Men become conscious of themselves, while women just go on as before. "Du bist. Ich werde". Robert Graves put this another way when he entitled a volume of poems Man does Woman is (1964). Grass is talking in a time-continuum which includes past and present, Charlemagne and the centuries before him as well as Ginter and Ilsebill with their soup and wine today. The generalities are applicable all along the line:

Dein kleiner Bezirk gesichert -

meine ganz große Sache gewagt,

but the emphasis on 'ich' is unmistakable. The next two lines sum up male supremacy: "Dein Flennen hilft nichts" and she is expected to put up with anal sex if he wants it. Then comes a passage which concentrates on Ilsebill "Meine kleine tapfere Ilsebill" and other similar generously condescending expressions, "die ich anbete, anbete" (this, we saw, was implicit in the first paragraphs of the book). While he (foolishly and condescendingly?) adores her, she is changing, "ganz anders fremd anders und sich bewußt wird". She is becoming conscious of herself, what men achieved long before Charlemagne, and Grass uses the same word for it. The poem finishes with another lapidary formulation. It is seen to be built round the two phrases, both addressed by Günter to Ilsebill: "Halt mal die Leiter, während ich steige" as an expression of male supremacy, and "Darf ich dir immer noch Feuer geben?" as the utterance of a man who has been rendered insecure by changes he only imperfectly understands, who is not sure whether the traditional gesture of (pseudo-) chivalrous courtesy, lighting a woman's cigarette for her, is going to be well received or whether Ilsebill is going to say: 'Thanks, from now on I can light my own'. This is the Ilsebill we got to know in the first paragraphs, and it is clear that there is something to be said for her. Division of labour has traditionally worked out so that men have all the interesting jobs and women all the drudgery, ever since the fish took a hand (a fin?) and freed Günter from slavery to Ilsebill-Aua. The tide is beginning to turn, and in the next section we are shown how the fish sets about supporting women instead of men. " 'Jetzt werde ich mich', sagte er wie zum Abschied, 'ein wenig um die Ilsebills kümmern müssen'" 
(p. 47). 'Arbeit geteilt' strikes the fundamental theme of the book, the equality of the sexes, but it states it in negative terms. We have a long way to go before it can be realised in positive terms.

The fish freed men from female servitude, at the price of enslaving women to men. That was not his intention; “' Manch eine Frau', sagt er, 'steht durchaus ihren Mann. Wie deine tüchtige Ilsebill. Das sollte anerkannt werden, mein Sohn, wie es von Anfang an, als ich mich freiwillig in deine Aalreuse zwängte, unsere wohlwollende Absicht gewesen ist" " (p. 45). The fish is well-intentioned, but he is not good at choosing his team. His men went beyond his intentions, and the women in whose power he voluntarily puts himself are blinkered ideologues; they not only reject his offer of help but put him on trial and condemn him for having boosted the male principle down the centuries and thus being responsible for capitalist exploitation, war and most other evils of our society. Who these women are we are shown in the next section, 'Wie der Butt zum zweiten Mal gefangen wurde' (p. $46 \mathrm{f}$ ), to which this poem is seen to lead over: "Drei hartgesottene Mädchen, die (wie du, Ilsebill) zur Gruppe der Dreißigerinnen zählen ... und die, wenn sie sprechen, nach jeweils ein paar Sätzen verächtlich ausspucken, ziemlich alles Scheiße nennen, beschissen finden oder bekackt". The cheap trendiness of their speech shows them up for what they are. The three friends constantly refer to an absent friend, 'unsere Billy'; it is not for some time that we realise that she is the Sibylle Miehlau who comes to a ghastly end in the chapter 'Vatertag' on 31 May 1962, when her three dear friends did nothing to help her, and that she is already dead when she is mentioned here. The fish has put himself at the mercy of these twisted characters who not only have already left one friend in the lurch in horrifying circumstances but who can talk about her as though there was nothing to it. "Ach Butt! Dein Märchen geht böse aus", Günter says later (p. 161). The poem we started with is inextricably involved with all this. As for the three friends, they have an unmistakable resemblance to Ilsebill, who talks the same sort of ideological gobbledygook, concentrated for us in the poem 'Manzi Manzi' (p. 176). She, like Sieglinde Huntscha (and Dorothea von Montau) has a 'Ziegengesicht'.

But there are also poems which seem to have no connexion with the context in which they stand, which are not points of concentration, like many of the others, but pauses, moments of rest, glances in another direction. One such is 'Mehrwert' (p. 210), which apparently begins with the word 'Oder' but really begins with the title: 'Mehrwert oder gefrorener Jubel'; the frozen jubilation is something extra, it is some object which the poet has collected 'zur Ansicht' on approval in the literal sense - for him to look at and get pleasure from. What is it? "Die Gläser auf meinem Brett": they are the frozen jubilation, they look well in oblique light. Not all of them are costly, Bohemian glass; some presumably are more humble, but are nonetheless frozen jubilation too. "Täglich sind zwei besonders." This is an incomplete sentence, one of Grass's 
effective tricks both in prose and verse; the reader must complete it, either with words or with association. It is association which is required here: each day two of the glasses are 'special' because they are used by two people (Günter and Ilsebill?) for some special purpose. 'Soviel Liebe zu Scherben bereit': the glasses now symbolise not just jubilation but love. They are special because the purpose for which they are used is rooted in love, precious but brittle, ' $z u$ Scherben bereit', ready to break into smithereens at any moment. Now we have, not what they mean but what they are: "Weithergeholt Atem, der nicht zerbrach" - the breath of the far away glass-blowers (some doubtless in Bohemia) solidified, brittle but not broken, beautiful, 'Luft und ihr Mehrwert', air and the something extra which makes it into art: the glass and the skill of the glass-blower. Glass-blowers, it seems, do not live long; they are subject to a number of occupational diseases. Their breath and what they make of it, lives on anonymously, crystallised in beauty 'zur Ansicht' for us to look at - at the price of the craftsman's burst lungs or blinded eyes. So behind this lies the word Marx coined for "der vom Arbeiter produzierte Wert, soweit dieser das Arbeitsentgelt übersteigt": 'Mehrwert', overvalue. Art is overvalue.

\section{IV. 'Vatertag'}

Fathers' Day in Berlin is described to us as the opposite of a family occasion, an exclusively male holiday: "ein ganzes Volk Männer, nur Männer fahren ins Grüne raus . . . Männer nur Männer wollen unter sich sein, ganz ohne Ilsebill, ledig der Röcke und Lockenwickler, wollen weg von der Brust, raus aus der Möse, frei vom Strickstrumpf, dem Abwasch, dem Haar in der Suppe, wollen außer sich sein und ins Grüne" (p. 575). An annual rite, at which certain ritual acts are performed - picnic with camp-fire, consumption of beer and hard liquor, singing and acrobatic feats, 'Kräftemessen', all exclusively male.

Alles was Mann ist, feiert am Himmelfahrtstag den Himmelhochvater, den Übersollvater. Und auch die Jungs auf ihren geputzten Motorrädern 'Ja ihr, da drüben am anderen Ufer' - die noch nicht wissen, wohin mit der Kraft, die sich in Leder geschmissen haben, schwarze Engel, mit Nieten beschlagen, wirklich wie Filmfiguren, die lässig federn und immer die richtige Witterung haben. Schlanke auf Lauer stehende Hechte (p.581).

Among the participants are four friends, lesbian women dressed as men and acting like men. We are told in some detail about their background. Three of them, Siggi, Mäxchen and Fränki, are identical with the three friends who angled the fish out of the Baltic (it was already hinted on p. 183). Now it is ten years earlier and the fourth member of the group is still there. Sibylle Miehlau from Danzig, refugee from the G.D.R., once married to Günter, now 'anders', as they say. She is the odd 'man' out in the group, feminine and uncertain in her lesbianism; even physically, with her attractive curves, she differs from the others; "Das Mäxchen sah aus wie ein menstruierender Junge, 
platt und fragil, während Sibylle die Maße eines Pin-up-Girls hatte: Typ Stars and Stripes" (p. 576). She has domestic instincts, lays the fire, and does the cooking and the little chores incident upon picknicking, for which the other three have no mind. The warmth of her personality is in clear contrast to the frigid egotistical hollowness of the others. Their brittle and artificial talk was already shown up in the scene with the fish; here, where we are directly concerned with their relations with one another, the endless bitchiness, the constant neurotic jealousies and the loveless struggles for dominance, it becomes even plainer and more odious. Women wrestling in mud. In any group of three or four there is apt to be a butt, a patsy, made fun of by the others with varying degrees of affection or malice; this is Sibylle, 'unsere Billy' of the fish scene, and she is it because she is too normal, too feminine.

This is a potentially explosive situation: the impact on a male rite of a group of transvestite women divided among themselves. There is a basic phoneyness which goes beyond mere play-acting or role-playing. The 'bierselige Horden' (p. 575) of men are playing out a ritual role; the four women have intentionally invaded this rite in order to assert their masculine otherness. They go to considerable lengths to do this. Mäxchen has bought a plastic penis, through which she can piss against a tree like a man (p. 588), followed by Fränki and Siggi; Billy is not allowed to try this exciting device, she has to do the cooking and the others refuse to help with the washing-up. Further male roles are acted out: 'Kräftemessen' in one form or another. Mäxchen climbs a tree (a phallic tree, p. 597), and the four join in an acrobatic performance, a 'Pyramide der Freundschaft' (p. 600), the base of which is the sturdy Sibylle. The brittle quality of this friendship is underlined by the circumstance that Mäxchen at the last moment won't play; the friends come to blows before the pyramid of so-called friendship comes off. All this is observed from a distance by different groups of men, one of which consists of hells angels, 'schwarze Engel' in leather jackets on motor-cycles. . The realisation grows that the performers are women, especially when Billy scares away a group of 'Korpsstudenten' by displaying her naked arse. The secret is out, the male sanctuary has been profaned, the rest follows like a Greek tragedy - and there is a Greek tragedy which applies.

But first, after all the food, the beer and the exercise, comes fatigue, hangover,let-down, sleep. Billy has worked harder than the others and sleeps deeper. All dream "den großen, eindeutigen, jede Nebenhandlung löschenden, nur auf sich bestehenden Zeugungstraum. . . der tiefer wummert als je gedacht und dessen urdumme Kraft sich auch dort steilt, wo die Natur nichts geplant hat" (p. 615), with the result that the plastic penis is used for a different purpose and the three friends rape with it the sleeping Billy, watched in horror from afar by the hells angels. This is the ultimate profanation of the male mysteries: "Die ganz dicke Sauerei. Den Kunstfick. Die Beleidigung aller vatertäglichen Saubermänner" (p. 617). Rudely awakened out of her 'Zeugungstraum' by this artificial procreation, the outraged Billy wanders off into the woods after 
saying goodbye to her friends and to lesbianism for good: "Ich geh jetzt. Mit euch will ich nie wieder. . . Wenn ich das will, nehm ich mir einen richtigen Mann. Der ist mir lieber. Das sage ich euch als Frau. Habt ihr verstanden! Als Frau" (p. 619).

The plastic penis: without bringing in female penis-envy and the rest of the psychological armoury it is clearly the ultimate symbol of feminist pretensions, of hollow phoneyness, of the profanation of a serious rite, and like all profanations it brings disaster in its train. Billy wanders off into the woods, marked from afar by the hells angels, who close in on her - we know already that for them "Son Tag ohne Bumsen ist keiner" (p. 592) - perform a brutal gang-rape and then run their machines over her until she is unrecognisably mangled. At the end of the day her dear friends, a trifle conscience-stricken ("wohl doch betroffen', p. 619) find the gruesome remains ("War das noch ein Mensch?", p. 621), ring up the police from the nearest call-box and make off home.

This deeply shocking, brilliantly related episode is the high point of a book which has many high points, and it has been recounted here in some detail for this reason. It takes effect on its own terms. But the effect is increased by a mythological dimension. A sacred male mystery is invaded by a female person dressed as a man, who is discovered and thereupon killed by participants in the rite. Put it the other way round: a male person dressed as a woman invades sacred mysteries restricted to women, is discovered and killed by the participants - and you have the story of Euripides's Bacchae: Pentheus is torn in pieces by maenads. The parallels extend even to minor details: Pentheus climbs a pine tree (line 1070), Mäxchen too climbs a pine tree (p. 597 f). Pentheus did it in order to observe the mysteries from a safe place, Mäxchen does it (typically) in order to show off ('Kräftemessen', male ploy). The final chorus of the Bacchae could sum up the events in 'Vatertag'; in the standard German translation by Ernst Buschor, which Grass might well know:
Was wir uns wünschten
Es ward nicht vollendet.
Für nie gehofftes
Fanden die Götter den Weg!
So kam auch dieses
Zum Ende.

But Grass adds an additional ironical twist. Billy is present on Fathers' Day dressed in men's clothes because she is a lesbian; if she was a normal woman she would not be there at all. She comes to her frightful end because she is a woman, just at the moment when she has realised that she is a normal woman ("die schöne Vatertagserkenntnis: 'Ich bin eine Frau, eine Frau, eine Frau!' " p. 623) she has, in the phrase Grass so often uses (as in the poem 'Arbeit geteilt') become conscious of herself. She thereby finds herself on the wrong side of the fence and dies tragically. The others undeservedly escape by virtue 
of appearing to be men. She attracts the hells angels precisely because she is obviously feminine: 'Pin-up-Girl, Typ Stars and Stripes'. The others, whose act of profanation was more serious, get off scot free because they are sexually unattractive. But their true character is thereby made plain - odious, sterile, hypocritical and cowardly, stumbling-blocks in the way of progress towards true equality of the sexes. Günter hates them, for here but for the grace of God goes Ilsebill. He loves Ilsebill (or thinks he does) and he feels he owes her something; it comes out between the lines that he once loved Sibylle (perhaps without quite realising it). He owes the others nothing and has no reason to conceal his feelings.

The result is a masterly job of demolition, gradually increasing in intensity as the book proceeds, and one which no reader is likely to forget. But the mindless young brutes on their motorcycles come off no better; seven to one, not in religious ecstasy like the maenads but inspired only by cold violence and hatred ('Drecksau, verdammte!' p. 624), they represent male dominance at its worst. They are a modern caricature of the description early on in the book of the violent 'Endzielmänner' down the ages (p. 44), even down to the crash-helmets and leather clothes:

Männer unter Lederkappen und Helmen mit nagelndem Blick, Männer mit schweifendem, die Horizonte abtastendem Auge. Zeugungswütige Männer, die ihre Stinkmorcheln zu Geschlechtertürmen, Torpedos, Weltraumraketen umdachten. Männer mit System, in Männerorden versammelt. ... Helden die nicht, nie und auf keinem Fall im Bett sterben wollten.

Billy is the only truly tragic figure in the book. Her fate is carefully led up to (she is mentioned early in the book, on p. 26); she is continually referred to, as though by the way; our interest is aroused; when she finally appears we are not disappointed. She dies an undeserving casualty in the sex-war, the victim of two gang-rapes.

There are further, remoter mythological associations which contribute subliminally to make her end unforgettable. Outraged by her friends she wanders off into the woods. The woods in Germanic mythology and folk-tale are dangerous places; it is best not to go there. 'Waldgang' in Germanic law was the penalty for serious crimes, including homosexual practices; 9 here too the woods take their toll. Grass himself says, in the poem Dreht euch nicht um:

Geh nicht in den Wald

im Wald ist der Wald.

Wer im Wald geht

Bäume sucht, wird im Wald nicht mehr gesucht.

And finally, 'Vatertag' is also the feast of the Ascension, ironically the feast 
of the irrevocable salvation of human kind.

Billy is not the only victim of a gang-rape in the book. Agnes Kurbiella, that image of selfless devotion, in the spring of 1632 at the age of thirteen was raped among the sand-dunes at Putzig by four Swedish soldiers. "Sie hütete ihre Gänse und hatte plötzlich alle vier über sich: nacheinander, schnell fertig. Doch nur der erste hat wirklich gezählt. Der ist ihr näher als später Möller und Opitz gewesen. Und der soll Axel geheißen haben. Und dessen flaumiger Knabenbart soll blond gewesen sein. Und dessen spröde Stimme behielt ihren Nachklang: befehlend. Der kam nie wieder und war ihr immer nah" (p. 343). This is in accordance with the widespread belief that women love the man best to whom they lost their virginity. What happened in the sand-dunes at Putzig was in the course of nature; we are not asked to condone it, approve it or condemn it; it is one of the things that tend to happen. It is true that Agnes was never quite right in the head afterwards (". . was ihren Verstand verkehret hat", p. 325), but she lived a useful life inspired by love and devotion to others, bearing Möller and Opitz each a child and acting as a muse to both of them. Indeed, so the fish says, "Sie war mehr als Möller and Opitz zusammen" (p. 324), to fall finally in her derangement for Quirinus Kuhlmann and to follow him to the stake in Moscow for witchcraft, though "Nur die unmusische Welt nannte Agnes verrückt, besessen, verhext und vom Belial geritten" (p. 357-8). Her end - it was reported back to Stockholm by the Swedish ambassador in Moscow Axel Ludström - is shocking enough; she was the victim of religious bigotry and incomprehension. Her life compared with Billy's - e.g. Agnes looked after her and Opitz's daughter Ursel, p. 357, whereas Billy disposed of her and Günter's child, whose name we never hear, to her parents, p. 585 - is natural and fulfilled; her end, though terrible ('entsetzlich starb Agnes', p. 524) was natural by the standards of her time. Her fate highlights 'Vatertag' by simple comparison; what happens to Billy is in a different category of horror; the one is natural, the other unnatural. We can accept the first, under protest; there is no reason why anyone should have to accept the second, but her three friends evidently could.

\section{Food and Sex}

As we saw, food and sex are linked at the very beginning of the book and it is not difficult to follow the thread through the whole. Both food and sex have always been among the recurring themes in Grass's work, especially his poetry and his graphics. They come together in various ways, not least in the phallic mushrooms which recur in his graphics and which play a part in Der Butt too; there is a mushroom strand in the story. (Sophie Rotzoll, cookhousekeeper to the Napoleonic governor of Danzig, poisons his guests with a calves-head stuffed with mushrooms, all for love; p. 477). Even in the early poems culinary images make themselves felt; we saw how the very first page of 
the novel takes up one such early poem. Another one is $I m E i$, the cosmic egg in which we all live, which one day some one is going to break into a pan and fry with salt; another is Koch und Löffel, and there is always the obsessive figure of 'die schwarze Köchin'. In Der Butt there is the poem 'Die Köchin küßt' (p. 295): a couple kissing over food, passing food from mouth to mouth in a kiss: "Vorgekaut Faserfleisch. Durch den Wolf gedreht, was zu zäh". Before the invention of the mincing-machine human jaws did the job. "Ihr $\mathrm{Kuß}$ füttert" even the dying poet (Opitz). This is a reciprocal activity (Und ich gab zurück'): "Einmal aßen wir einen Hecht von der Gräte; ich ihren, sie meinen. ... Und einmal machte im Sauerkraut Kümmel uns lustig, den wir tauschten und tauschten; hungrig nach mehr". An act of love: "Einmal (und immer wieder) küßten wir uns an Bohnen satt" - and the beans recall the beans with the mutton on the first page. But an even more startling case of this association of food and sex occurs in the scene in which Günter is present at the birth of his child by caesarian section: "Außerdem sah ich noch, wie gelb, ähnlich Hühnerfett, Ilsebills Bauchfett ist. Ich hätte damit, weil ein Stück abfiel, zwei Spiegeleier braten können" (p. 680). Here, quite suddenly, the cannibalistic overtones of metaphorical phrases like 'nett zum Anbeißen', 'ich könnte Dich auffressen, so schön bist Du' appear within the realm of possibility, and an alarming train of thought is opened up which the author is careful not to pursue any further.

Another strand is concerned with fruit, especially apples and cherries (both common sex symbols in folklore); the poem Kirschen and the phrase from it, "Wer küßt hier wen" is taken up on page 259. Eudo Mason said that "it would be easy to write a study of 'Rilke and the Apple' and to make of it a comprehensive interpretation of his personality, outlook and art"; 10 one could almost say the same about Grass. Already apple-cores occur and recur in his graphics and in one of a series of poems published with accompanying etchings in 197411 there is an etching of two apples, each with a bite taken out of it, and the accompanying verses, which are relevant to the theme of Der Butt:

\section{Liebe geprüft}

Dein Apfel - mein Apfel.

Jetzt beißen wir gleichzeitig zu:

Schau, wie auf ewig verschieden.

Jetzt legen wir Apfel und Apfel

$\mathrm{Bi} ß$ gegen $\mathrm{Bi}$.

Each is different but each is equally valid, as each bites into the apples of love. The scene in the poem is evoked with verbal reminiscence and set against a wider background in the chapter 'Nagel und Strick' in the novel (p. 527), which also takes up the theme of twisted nails which occurs in the graphics without apparent relevance and gives it significance - a man tries to hang himself from one such nail. The associations of the apple are multiple; an investigation could 
start from this point.

The accumulation of detailed information about food and especially about how to prepare it is quite remarkable, and has its forerunners in the earlier books. There is by now sufficient material to make an anthology of such pieces, a 'Günter Grass Cook-Book' which would only need the addition of precise details of times and quantities for it to be of practical use in the kitchen. And a cook-book even has its place in the novel: Lena Stubbe's proletarian cook-book, which never got into print and the manuscript of which is now lost. We hear of her "unerschöpfliche Liebe, die dem großen, nie leeren Suppentopf in der Wohnküche glich" (p. 520). The proletarian cook-book had one excellent point: previous cook-books were modelled on bourgeois eating habits and on bourgeois incomes, with the result that working-class cooks took recourse to tinned stuff (p. 551). Lena Stubbe's manuscript was ready for the press in 1896, when August Bebel was her guest in Danzig to beef-bone soup and pig's kidneys with mustard sauce (p. 548). This was forty-four years after Charles Elmé Francatelli had published $A$ Plain Cookery Book for the Working Classes not for the first time, for the date of the first edition seems to be unknown in London in 1852.12 Francatelli's background was quite different from Lena Stubbe's; he describes himself on the title-page as 'late mâtre d'hôtel and Chief Cook to Her Majesty the Queen'; he is not concerned with the actual eating habits of the working classes but with telling them how to make good nourishing food - of the kind to which he was accustomed - cheap. He is concerned not only with the day-to-day but with special meals as well, 'more tasty dishes for the birthday, Christmas-day or other festive occasions' (p. 9). There is mention of pig's feet there but not of anything resembling Lena Stubbe's tasty dish of them or of her dish for a special occasion, the pig's kidneys with mustard sauce (but see no. 73, 'Belgian Faggots'). The kitchen depicted in the frontispiece seems to be larger and more roomy than Lena Stubbe's 'Wohnküche' can have been. His book was published seven years after Friedrich Engels's Die Lage der arbeitenden Klasse in England (1845), which paints quite a different picture. By comparison, Lena Stubbe's ideas are confidenceinspiring; she obviously knew what she was talking about better than Charles Elmé Francatelli, who conveys the impression that the working classes are not really poor (he tells them for instance how to prepare Baked Sucking Pig, no. 27) but simply ignorant and feckless (no. 121, To Fry Fish: 'For this purpose you must have some kind of fat'). He was looking at working-class life from the outside, and this is confirmed by his appendix entitled 'Economical and Substantial Soup for Distribution to the Poor' (p. 99). By contrast, Grass makes us feel that Lena Stubbe is looking at it from the inside, that for her food, and especially soup, goes together with love and service to others, right down to the canteen in the concentration-camp at Stutthof where she ended her life at the age of ninety-three. (Sibylle Miehlau was her great-granddaughter; "wie alles sich zum Ganzen webt. .."). 
Among all these cooks the real sex-pot is the only nun in the series, Margarete Rusch in sixteenth-century Danzig, who is emancipated in her own way and emancipates the nuns in the convent of which she is abbess. She does not try to be a man, like the 'Manzis', but simply exploits to the full her resources of food and sex. Both are sources of pleasure as well as power, and she welcomes sex in all its forms, entirely divorced from love, 'dieses Wimmergefühl' (p. 249). Food and sex as power: of the two men responsible for the execution of her father, one she stifled in bed with her hundredweight of fat in the act of sex, the other she fed and fed ("Die Herrens koch ech miä ab midde Zeit", p. 256, 277) until he died of a plethora over a dish of her famous tripe fifty years later ("So lange lebte die dicke Gret ihrer Rache", p. 254, 266). In the sixteenth century, so the fish tells us, the only free, that is emancipated, women who had full power over their persons, who were liberated from the monopolistic slavery of the marriage-bed and the nursery, were nuns and prostitutes, and then only if they knew how to exploit their advantages (p. 263, 270f). "Nicht etwa die zänkischen, immer in Eifersucht gehaltenen Ehefrauen, nein die Nonnen und Hürlein übten jene weibliche Solidarität; die heutzutage auf Kongressen und in Kampfschriften zu Recht gefordert wird". 'Die dicke Gret' is also the only woman in the whole book of whom it is expressly stated that she has a sense of humour - a hugely Rabelaisian one; "ihr Gelächter hat den Frauen Spielraum und jene Freiheit geschaffen, in der Humor, nun endlich auch weiblicher Humor seine Knallfrösche springen und die ganz große Sau loslassen darf" says the fish (p. 276), but that does not go down well with the Feminal; Sieglinde Huntscha replies in the jargon with which we are by now familiar. She thereby unwittingly reveals an uncomfortable fact: there is a ghastly puritanical humourlessness about all these emancipated women, whose fanaticism excludes human emotions; Margarete Rusch's laughter, her unashamed sensuality, her mother-wit (yes, mother-wit) shows them all up.

'Die dicke Gret' has certain traits in common with Villon's 'grosse Margot'. The 'Ballade de Villon et de la grosse Margot' is one of the best known of Villon's ballades in Germany because of the use Brecht made of it in the ' $\mathrm{Zu}$ hälterballade' in the Dreigroschenoper. It is interesting to see what Grass does with it.

'La grosse Margot' first appears in stanza 140 of the Grand Testament; Villon bequeaths to her 'tresdoulce face et pourtraicture', from which we may conclude that if she needed these she was no beauty (in the following ballade she is compared with a dungbeetle, 'escarbot'). We hear nothing about Margret's appearance except that, like Margot, she was fat. Margot is mentioned in a context involving the convents of the Jacobins, Carthusians and Celestines; Margret is a nun and becomes the abbess of her convent. Here already we see Grass taking up an apparently unimportant detail in his source and elaborating it. Margot is 'assez dévote créature', and this remark is surely ironical; Margret is not only a nun, but is expressly stated to be pious (not entirely without 
irony too): "Dabei war Margret fromm. Noch den flüchtigsten Lustgewinn hat sie dem lieben Gott mit einem Dankgebet verrechnet" (p. 214). The famous ballade immediately following has the refrain "En ce bourdeau où nous tenons nostre estat"; the parallel between convents and brothels was often remarked upon and is a commonplace in Shakespeare. The convent of which Margret Rusch was abbess became, we are told, under her direction little better than a discreetly run brothel (p. 248-9). Here she is in control and can keep a succession of 'bettgerechte Küchenjungen' (p. 262). She has found a way out of the situation of male dominance, a way open, as we saw, in those days only to whores and nuns. Margot on the other hand, though a whore, is still in subjection, she has her ponce who beats her up if she comes home without any money:

\section{Mais, tost après, il y a grant deshait}

Quand sans argent s'en vient coucher Margot.

Margret and her nuns were also concerned with money for sex: "Immer solle des Mannes Dank in Silber zu wägen sein" (p. 249), and we are further told that she increased the wealth and influence of the convent by her cookery (p. 262).

'Puis, paix se faict, et me lasche ung gros pet'- Margret too 'glaubte an die befreiende Kraft des Furzes' (p. 266). Out of this one line Grass has spun a couple of memorable passages about farting, including the remark "Wer den Furz seiner Liebsten nicht riechen kann, der soll nicht von Liebe reden" (p. 259). This is another instance of the way one simple impulse sets Grass's mind working and of how he causes an elaborate plant to grow out of an inconspicuous seed.

'Riant, s'assied son poing sur mon sommet' - Margot laughs, and we saw how important Margret's laughter is; the one word 'riant' in this context of Villon's poem becomes a constituent trait of the personality of Margret Rusch. Margot is 'grosse' not only because she is fat but also because she is pregnant ('que ne gaste son fruict'). Margret was twice pregnant, and was so fat that her pregnancies passed almost unnoticed (p. 263). Here again a subsidiary trait is elaborated into something more important: Margot, because she is pregnant, mounts her man - 'monte sur moy'. Margret does so too, but for a different reason: for her it symbolises her victory over men ("Väter waren ihr allemal lachhaft", p. 263). In both cases the man is exhausted:

Soubz elle geins, plus qu'un aiz me faict plat,

De paillarder tout elle me destruict;

and Grass relates:

Auch hielt die dicke Gret nicht ergeben still, sondern war ihren rasch erschöpften Bettgenossen dergestalt gewichtig obendrauf, daß es mir oft die Luft nahm. Regelrecht unterdrückt hat sie mich. Käsig lag ich danach und wie abgenippelt. Mit Essigwasser hat sie mich reiben, beleben müssen (p. 263-4). 
It was in this way that she killed Eberhard Ferber - this too a startling elaboration of a minor trait in the original.

Villon loves Margot 'de propre nature' (whatever the precise significance of this apparently ironical remark may be) 'et elle moy, la doulce sade'; the irony here is made explicit by Margret Rusch who, though greatly interested in sex, has as we saw no use for love. Margot has got what it takes: 'Elle a en soy des biens à fin souhaict', and so has Margret. Villon knows he is on to a good thing; in the envoi of his ballade, summing up the situation, he can say 'Vente, gresle, gelle, j'ay mon pain cuict!' - come hell or high water he gets his greens. And this culinary phrase takes us back to the combination of food and sex which runs through the whole of Grass's novel.

It would be oversimplifying to suggest that Villon was the direct 'source' for the figure of Margret Rusch; such a complex and differentiated character is the result of a very different creative process. But 'la grosse Margot' offered certain traits which doubtless fitted what Grass had in mind already and which he could elaborate in accordance with his own intention in his own inimitable way.

\section{India}

If 'Vatertag' is a high point in the novel, so is the account of Grass's (not Günter's) visit to India, and one may well ask oneself why it is there at all. After all this talk about food, this section is about hunger; after all this talk about sex, this section is about endless procreation and where it leads: it leads to famine. Here too there is a dominating nun, a very different character this time: Mother Theresa, who has since been awarded the Nobel Peace Prize for selfless devotion and Christian love. The section fits into the historical timescheme of the novel by the device of making Günter also Vasco da Gama (who rounded the Cape and found the sea route to India in 1498, the year of Margarete Rusch's birth) and making Margarete Rusch marry off one of her daughters (these women never have sons) to a Portuguese merchant who traded in spices and provided her with pepper direct from Cochin. This device, though neat, seems to be rather far-fetched. The thematic contrast itself is reason enough for the inclusion of this section. Here we are in the present day; Grass goes to India by jumbo jet, not round the Cape.

The female couterpart to Mother Theresa is the goddess Kali, whose temple is next door to Mother Theresa's 'Sterbeheim' (p. 236), the goddess of death and destruction. The combination of hunger, filth and procreation is too much even for the great expressive power of Grass. His account of it is on the one hand a brilliant piece of high-grade reporting, of first-rate journalism, on the other hand is a confession of failure. "Er sah das Leben vor dem Tod" (p. 237). How is one to come to grips with human poverty and misery on this scale? One attempt seems cheap and frivolous: "Warum nicht ein Gedicht über den Haufen Scheiße, wie Gott ihn fallen ließ und Kalkutta nannte, wie es wimmelt, 
stinkt und immer mehr wird" (p. 235) - there is excrement everywhere. This is an attempt to give significance to phrases like 'am Arsch der Welt', and one respects the helplessness; it becomes a cheap jeer however in the next sentence: "Hätte Gott einen Haufen Beton geschissen, wäre Frankfurt herausgekommen" (Hence the pyramids?). But the next sentence after that goes beyond it: "In einem Gedicht über Kalkutta sollte Hoffnung nicht vorkommen". And the next following poem, 'Drei Fragen' ("Wie kann ich ... lachen? Wie sollte ich ... über die Schönheit reden? . . . Wie will ich . . über die Köchin schreiben?") has as the culminating line: "Ich suche ein Wort für Scham" (p. 239). This is a new dimension:

Das ist zuviel alles.

Etwas muß gestrichen werden: Indien oder der Oligarchische Kollektivismus oder die familiäre Weihnacht (p. 240)

against which the feminist aspirations of Sieglinde Huntscha and her like are seen to be trivial.

VII. The Novelist as Literary Historian and Parodist

Grass's historical sweep through the ages also involves literature. We are shown literary figures and made acquainted with what they wrote or may be deemed to have written. This is a comparatively new aspect of Grass's work, which has since expanded into a whole new book, Das Treffen in Telgte (1979), a recognisable spin-off from Der Butt. It is natural enough that Grass's intensive research on the historical background should give rise to a next step, a creative or re-creative evocation of some at least of the literature, out of sheer fellowfeeling of the artist for other artists. It is not all equally successful. The mixed High Alemannic and Low Prussian of Dorothea von Montau (pp. 167, 179, 196), is perhaps not entirely successful though mixed dialect texts of this kind are frequent enough and the references to her cookery have warrant in the sources.13 Grass has a happier touch with the baroque poets; the scene between the aging Opitz and the young Gryphius is convincing on its own terms; how Gryphius reproaches the admired maestro for having "seine Kraft politisierend vergeudet ... er . . . habe der Diplomatie gegeben, was er der Poeterey schuldig geblieben sei" (p. 308) and what he indeed owed not only poetry but the existential human predicament; and how Opitz replies, as much for Grass as for himself, that he sees himself as a man of peace, of the middle way among so much bloodshed, "ihn trüge keine Partei, sondern der Wunsch nach Duldung jeglichen Glaubens" (p. 310). This contrast is further worked out in Das Treffen in Telgte, which takes place in 1647, so Opitz is dead, but Gryphius is again the spokesman of existential need. This whole subject would need a chapter to itself; a further instance is the account of the alternative version of the folktale about the fisherman and his wife in 'Küstenplatt'. Parody as creative interpre- 
tation, as a labour of love. But Grass falls short of the great masterpiece of this kind, Thomas Mann's Lotte in Weimar.

\section{VIII.}

Even more than Grass's earlier novels this one is crammed with lively fleshed out figures, in whom we believe while we read about them, and some of whom stay with us after we have closed the book. Beside all the others there are the various cooks, whom the narrator - here surely not merely Günter but Grass too - has inside him; he repeatedly uses phrases like 'inwendig reich an Figuren' (p. 234), 'inwendig voller Figuren' (p. 227), 'So hockt sie in mir und schreibt sich fort' (p. 268); the figures are not thought out or consciously invented or contrived, they are already there, struggling to get free and out on to the pages of the book. This has always been so in Grass's writing.

Noch hält die Tür. Doch wenn sie bersten wird, wirst du mir Streit bringen odẹr mit deiner Frage 'Hast du zwei Markstücke für den Automaten?' mich nach Markstücken suchen lassen. Aber dann ging die Tür sacht und Agnes kam, beugte sich über mich, meinen Kritzelkram und sagte Spielworte. Ich weiß nichts Besseres, als diese Angst oder Hoffnung auszuhalten und - während die Tür noch hält - meine Striche und Punkte zu setzen. Hier bin ich zu haben, wenn auch nie ganz (p. 351f).

'Du' is Ilsebill, but when the door opens it is Agnes. The poet is sought out by his muses, all eleven of them, who demand to be brought into world by the poet's lines and dots, loops and pothooks or, as Ilsebill would say, to be 'emancipated'. "Sollen sie doch!" he says (p. 14). And they are.

Notes

1 Page references in brackets in the text are to the hard-cover edition, Luchterhand Darmstadt u. Neuwied 1977; titles of poems in quotationmarks refer to poems in that book; titles of poems in italics refer to Günter Grass, Gesammelte Gedichte (Sammlung Luchterhand 14), Darmstadt 1971.

2 This point seems to have been missed by many readers, who see Der Butt as an antifeminist book, but it is brought out strongly by H.R. Müller-Schwefe, Sprachgrenzen, das sogenannte Obszöne bei Günter Grass und Heinrich Böll, Munich 1978 and rather less strongly by Noel L. Thomas, "Günter Grass's Der Butt: History and Significance of the Eighth Chapter ('Vatertag')", GLL(NS). XXXIII (1979-80), p. 75 ff. $\mathrm{My}$ article was written without knowledge of his; I am glad that our different approaches often lead to congruent conclusions. In particular I applaud his use of 'turbot' for 'Butt'; 'flounder' seems to be an americanism, to judge by a comparison of Webster and $O E D$. 
3 Known versions of the tale are printed by Heinz Rölleke, Der wahre Butt, Düsseldorf 1978. See also J. Bolte and G. Polívka, Anmerkungen zu den Kinder- und Hausmärchen der Brüder Grimm, Leipzig 1913, I. p. 75 ff.

4 Stith Thompson, Motif-Index of Folk-Literature, Copenhagen 1932-6, F 546. 2. There are Celtic cases of persons with three or more paps: C. Plummer, Vitae Sanctorum Hiberniae, Oxford 1910, I., p. clviii, note 2. Compare also Artemis multimammata, W. Roscher, Lexikon der griechisch-römischen Mythologie, Leipzig 1884 ff, I. p. 596.

5 Gaston Bachelard, La psychanalyse du feu, Paris 1965, p. 64; see also Geza Róheim, The Panic of the Gods, Harper-Torch New York 1972 and C. Perlès, Préhistoire $d u$ feu, Paris 1977.

6 This aspect is given special attention by Noel L. Thomas, op. cit.

7 There is a rich literature on this subject; see for instance Anne-Marie Rocheblave-Spenle, Les rôles masculins et féminins, Paris 1964.

8 'Bohnen und Birnen', Gesammelte Gedichte p. 21.

9 Karl von Amira, "Germanisches Recht", 4. Aufl. Berlin 1967, II., p. 134, 140 , in Hermann Paul, Grundriß der germanischen Philologie 5/2; J. Hoops, Reallexikon der germanischen Altertumskunde, Strasburg 1918, IV., p. 184, s.v. 'Sittlichkeitsdelikte'; Andreas Heusler, Kleine Schriften, Berlin 1943, I. 2, p. 316.

10 Eudo. C. Mason, Rilke, Europe and the English-speaking World, Cambridge 1961, p. 20-21.

11 Günter Grass, Liebe geprüft, Sieben Gedichte mit sieben Radierungen, Bremen 1974.

12 Reprint Scolar Press, London 1977.

13 Hans Steinger in Verfasserlexikon des deutschen Mittelalters, Berlin 1933, I., p. 453 ff; Th. Hirsch, Scriptores rerum prussicarum, Leipzig 1863 , II., p. 248-9. 